\title{
Flow Birefringence in the Polymerization of Fibrinogen Catalyzed by Thrombin and Undetectable in Reptilase Systems under the Corresponding Conditions
}

\author{
Hiroko SATo and Yasuyuki Mızuı* \\ Research Center for Medical Polymers and Biomaterials, Kyoto University, \\ 53 Kawaharacho, Shogoin, Kyoto 606, Japan \\ *Wakenyaku Co. Ltd., 25 Nishi-ioricho, Kitashirakawa, Kyoto 606, Japan
}

(Received August 1, 1988)

\begin{abstract}
Flow birefringence was observed during the polymerization process of fibrinogen catalyzed by thrombin under the experimental conditions for the formation of fine clots at a much smaller velocity gradient than in the previous observation. No flow birefringence was detected in the case of fibrinogen catalyzed by Reptilase under the corresponding conditions. This is a clear evidence implying the role of a polymerization site formed by the release of fibrinopeptide $\mathrm{B}$, abbreviated as FPB, from fibrinogen. That is, both fibrinopertides A-, abbreviated as FPA-, and B-released fibrinogen play important roles to form oriented fibrin intermediate fibers. A polymerization site, revealed after the release of FPB, was considered to bind with its complementary site to grow along the direction of the axis of protofibrils. But protofibrils, formed by FPA-released fibrinogen, seem more rapidly to aggregate toward the lateral direction than FPA- and FPB-released fibrinogen. Although clots formed by thrombin and Reptilase have been observed to be very similar in structure, they could be distinguished under flow birefringence observation.
\end{abstract}

KEY WORDS Flow Birefringence / Fibrin Monomer / Thrombin /
Reptilase / Assembly / Protofibrils / Lateral Aggregation /

Thrombin releases fibrinopeptide A (FPA) and fibrinopeptide B (FPB) from fibrinogen. The des-AABB fibrinogen polymerizes automatically, and then causes the formation of fine clots at high ionic strength and/or at high $\mathrm{pH} .{ }^{1}$ At lower $\mathrm{pH}$ or/and ionic strength coarse clots are formed. Under the corresponding experimental conditions, clots formed with Reptilase, releasing only FPA from fibrinogen (des-AA fibrinogen). Very similar clots formed with thrombin in optical appearance (e.g., the optical or turbidity of clots). Moreover, fine and coarse clots formed by thrombin ${ }^{2}$ were very similar to those formed by Reptilase under electron microscopic observation.

Fine clots formed with Reptilase showed remarkable differences in stress relaxation. ${ }^{3}$ This means that Reptilase fine clots were more fluid than thrombin fine clots. ${ }^{3}$ In addition, clots formed with thrombin were more in- accessible to hydrolysis by plasmin, compared with clots formed with Reptilase. ${ }^{4}$ Laurent and Blombäck ${ }^{5}$ observed the difference by dissolving clots formed with both enzymes in $1 \mathrm{M}$ urea and measuring the light scattering of the solution, and proposed on the basis of differences in light scattering that the structure of fibrin formed with thrombin was laterally aggregated.

The present work examines the effects of different structures in the polymerization of fibrin monomers formed by thrombin and Reptilase as observed by flow birefringence.

\section{EXPERIMENTAL}

Bovine fibrinogen, $95 \%$ clottable, was purchased from Miles Lab. Inc. (Lot. 100), and Reptilase, extracted from Bothrops atrox venom, was purchased from Sigma Chemical Co. 
(Lot. 64F9452). Bovine thrombin was generously prepared by Mr. K. Ueda in Mochida Pharmaceutical Co., Ltd.

Flow birefringence measurements were carried out under various conditions for the formation of coarse clots and fine clots. Figure 1 shows the formation of coarse and fine clots catalyzed by thrombin and Reptilase under various experimental conditions. Under experimental conditions 1,2 , and $2^{\prime}$, as described in Figure 1, clots catalyzed by thrombin or Reptilase were almost transparent gel, i.e., fine clots, while clots formed at $\mathrm{pH} 7.0$ in a low ionic strength resulted in highly turbid gel, i.e., coarse clots under experimental conditions 3 , $3^{\prime}$, and 4, as descrbed in Figure 1. In addition, no clotting was observed for fibrinogen, catalyzed by a large amount of Reptilase $([R]=$ $0.294 \mu \mathrm{g} / \mathrm{ml}$ ) in a Tris- $\mathrm{HCl}$ buffer at $\mathrm{pH} 9.5$, $0.3 \mathrm{M} \mathrm{NaBr}$. The amounts of thrombin or Reptilase used for flow birefringence measurements were about $1 / 10$ as much as the amount necessary for the clotting time to be $200-400 \mathrm{~s}$ for about $1 \mathrm{mg} / \mathrm{ml}$ fibrinogen solution, using a BBL Fibrometer.

For birefringence measurements, $120 \mu \mathrm{l}$ of $1 \mathrm{mg} / \mathrm{ml}$ fibrinogen solution were added to a small aliquot of thrombin or Reptilase in a cell. Then, the small cell with a light path of 1 or $3 \mathrm{~cm}$ was rotated at a given velocity gradient $G$. The birefringence $\Delta n$ was detected at angle $\delta$ by the clear chromatic appearance of purple; $560 \mathrm{~nm}$ was used for calculations. The inner diameter of the cell was $0.6 \mathrm{~cm}$, while the outer diameter of an immobile cylinder was $0.56 \mathrm{~cm}$. The flow birefringence apparatus (Wakenyaku Co., Ltd., Micro FBR Model 2100) was equipped with a xenon or tungsten lamp as the light source, and modified for the measurement in a minor amount of samples. Flow birefringence of $\mathrm{F}-\mathrm{T}$ and $\mathrm{F}-\mathrm{R}$ systems was measured in buffers such as $0.01 \mathrm{M}$ Tris- $\mathrm{HCl}$ buffer at $\mathrm{pH} 9.5$ containing $0.3 \mathrm{M} \mathrm{NaBr}$ (Buffer I), and $0.05 \mathrm{M}$ phosphate buffer at $\mathrm{pH} 7.0$ containing $0.2 \mathrm{M} \mathrm{NaBr}$ (Buffer II), and $0.05 \mathrm{M}$ phosphate buffer (Buffer III).

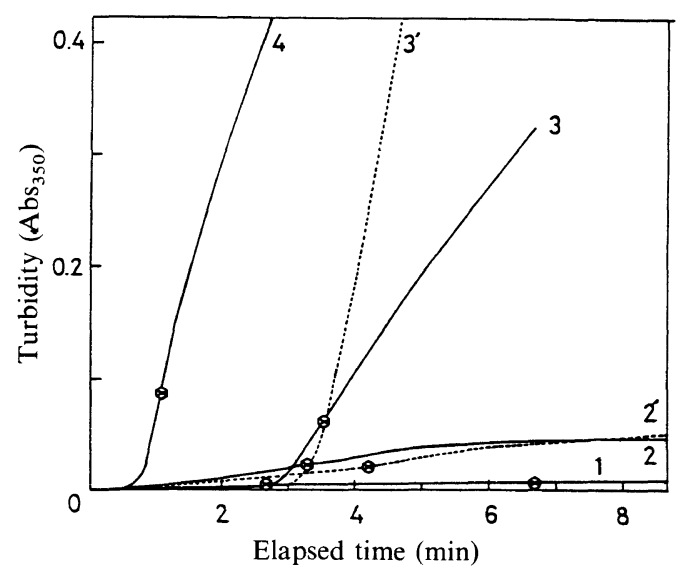

Figure 1. Turbidity-time curves in F-T (-) and R-T (---) under experimental conditions for the formation of fine $\left(1,2\right.$, and $\left.2^{\prime}\right)$ and coarse $\left(3,3^{\prime}\right.$, and 4) clots. $[\mathrm{F}]=0.996-0.923 \mathrm{mg} / \mathrm{ml} ; \otimes$, clotting time. 1 , $[\mathrm{T}]=8.125$ units $/ \mathrm{ml}$ in a $0.01 \mathrm{M}$ Tris- $\mathrm{HCl}$ buffer at $\mathrm{pH}$ 9.5, 0.3 M NaBr (=Buffer I); 2, [T] =0.385 units $/ \mathrm{ml} ; 2^{\prime}$, $[\mathrm{R}]=0.02 \mu \mathrm{g} / \mathrm{ml}$ in a $0.05 \mathrm{M}$ phosphate buffer at $\mathrm{pH} 7.0$, $0.2 \mathrm{M} \mathrm{NaBr}$ (=Buffer II); 3, [T]=0.0207 units $/ \mathrm{ml} ; 3^{\prime}$, $[\mathrm{R}]=0.002 \mu \mathrm{g} / \mathrm{ml}$ in a $0.05 \mathrm{M}$ phosphate buffer at $\mathrm{pH} 7.0$ (=Buffer III); 4, [T] $=0.0769$ units $/ \mathrm{ml}$ in Buffer III.

As the reference samples, protofibrils of fibrin and actin were investigated, because their structures have been well studied by flow birefringence. The fibrin protofibrils were formed in a solution of $0.5 \mathrm{M}$ hexamethylene glycol (HMG), $0.05 \mathrm{M}$ phosphate buffer at $\mathrm{pH}$ 6.5 and $0.48 \mathrm{M} \mathrm{KCl}^{6}$ by adding $1 \mathrm{unit} / \mathrm{ml}$ thrombin to $1 \mathrm{mg} / \mathrm{ml}$ fibrinogen in a $0.05 \mathrm{M}$ phosphate buffer at $\mathrm{pH} 6.5$ and $0.66 \mathrm{M} \mathrm{KCl}$, and then adding a concentrated $\mathrm{HMG}$ solution. The viscosity of a $0.5 \mathrm{M}$ HMG solution, measured by an Ostwald type viscometer, was 1.23 times that of pure water at $25^{\circ} \mathrm{C}$. After the incubation in the HMG solution for $52 \mathrm{~h}$, a small amount of precipitate was removed from the fibrinogen-thrombinHMG solution by filtration. The viscosity of the solution increased to 1.27 times that of the $1 \mathrm{mg} / \mathrm{ml}$ fibrinogen solution containing $\mathrm{HMG}$, phosphate buffer, and $\mathrm{KCl}$. Therefore, the protofibrils were believed to be formed as an inhibited aggregate to fibrin. Since the chromatic change in a $0.829 \mathrm{mg} / \mathrm{ml}$ protofibril 


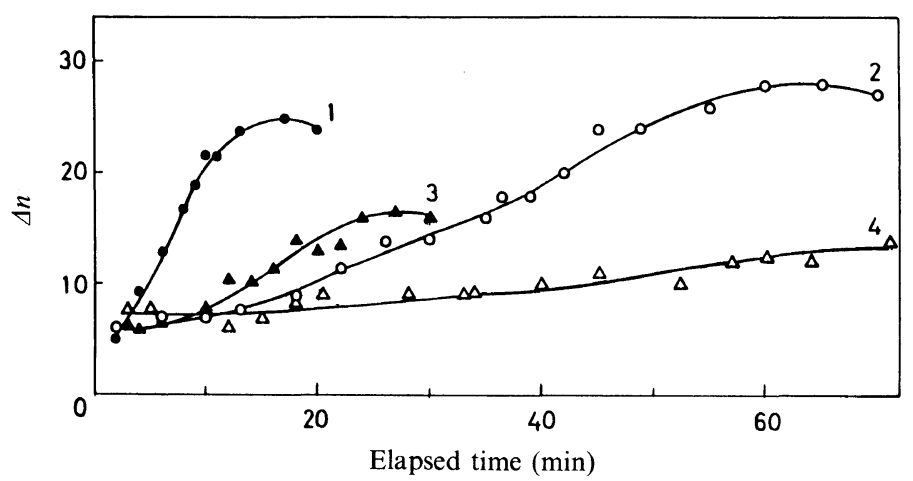

Figure 2. Time dependence of flow birefringence, $\Delta n$, at velocity gradient of $1670 \mathrm{~s}^{-1}$ in $\mathrm{F}-\mathrm{T}$ systems under various experimental conditions. $[\mathrm{F}]=0.923 \mathrm{mg} / \mathrm{ml} .1,[\mathrm{~T}]=0.0769$ units $/ \mathrm{ml}$ in Buffer $\mathrm{I} ; 2,[\mathrm{~T}]=$ 0.0385 units $/ \mathrm{ml}$ in Buffer I; 3, $[\mathrm{T}]=0.0385$ units $/ \mathrm{ml}$ in Buffer $\mathrm{II} ; 4,[\mathrm{~T}]=0.0192$ units $/ \mathrm{ml}$ in Buffer II.

solution was weak under conditions of flow birefringence measurements, the appearance of the purple color in the protofibril solution was clearly observed with a cell having a light path of $3 \mathrm{~cm}$.

Actin was purified from rabbit back and foot muscle by Dr. K. Takagi, Kyoto University, and used as the standard sample for flow birefringence. The actin was dissolved in a $G$-buffer at $\mathrm{pH} 8.0$, containing $3 \mathrm{mM}$ imidazole, $0.1 \mathrm{mM} \mathrm{CaCl} 2,0.5 \mathrm{mM} \mathrm{ATP}$, and $0.75 \mathrm{mM} \beta$-mercaptoethanol, and polymerized rapidly in $0.1 \mathrm{M} \mathrm{KCl}$ at the final concentration.

\section{RESULTS AND DISCUSSION}

In fibrinogen and thrombin $(\mathrm{F}-\mathrm{T})$ systems, no flow birefringence was observed on the first and third quadrants. It indicates that the direction of the optical polarization of fibrin monomer unit in formed particles coincides with the direction of orientation of formed fibrin particles or fibrin intermediate fibers and protofibrils. Figure 2 shows the increase in the critical angle $\delta$, where the flow birefringence, $\Delta n$, is detected eminently, as a function of the time elapsed after mixing fibrinogen with thrombin. Immediately after mixing fibrinogen and thrombin, the mixtures prepared under various experimental conditions were rotated

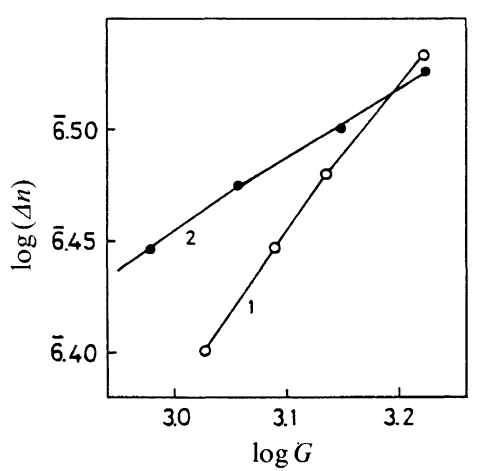

Figure 3. Maximum flow birefringence $(O)$ in the polymerization process and $\Delta n$ values (O) of once formed particles are plotted against consecutively decreasing $G$ values in a logarithmic scale. $1,[\mathrm{~T}]=0.0769 \mathrm{units} / \mathrm{ml}$, $[\mathrm{F}]=0.923 \mathrm{mg} / \mathrm{ml}$ in Buffer $\mathrm{I} ; 2,[\mathrm{~T}]=0.0278 \mathrm{units} / \mathrm{ml}$, $[\mathrm{F}]=0.889 \mathrm{mg} / \mathrm{ml}$ in buffer II.

at a given velocity gradient. The flow birefringence of a fibrinogen solution of $1 \mathrm{mg} / \mathrm{ml}$ in the absence of thrombin, that of $\mathrm{F}-\mathrm{T}$ and fibrinogen and Reptilase ( $\mathrm{F}-\mathrm{R})$ systems at low ionic strength, and that of $\mathrm{F}-\mathrm{R}$ systems at high ionic strength were not observed under the measured velocity gradient. ${ }^{7,8}$ Clear chromatic polarization could be observed as the results of polymerization of fibrin monomer by thrombin proceed in both $\mathrm{pH} 7.0$ and $\mathrm{pH} 9.5$ buffers in high ionic strength. In Figure 3, values of flow birefringence maxima are plotted in a logarithmic scale against velocity gradient in 
the conversion process of fibrinogen-fibrin catalyzed by thrombin under a constant velocity gradient. As seen in the same figure, values of flow birefringence for once formed particles decrease with decreasing velocity gradients. The following stress-optical law holds between the observed flow birefringence $\Delta n_{\max }$ or $\Delta n$ and the stress $\Delta \sigma$ to each formed fibrin particles.

$$
\Delta n_{\max }=c \Delta \sigma
$$

where $c$ is a function of viscosity, concentration $v_{2}$ of solutes, and extinction angle for the flow birefringence measurement. At the same time, $\Delta n$ is expressed by

$$
\Delta n=2 \pi v_{2} f\left(g_{1}-g_{2}\right) / n
$$

where $n, f$, and $\left(g_{1}-g_{2}\right)$ imply the refractive index of a buffer, orientation factor, and function for the optical polarizarion of particles.

On the other hand, no chromatic polarization was observed in $\mathrm{F}-\mathrm{R}$ systems under conditions for the formation of both fine and coarse clots, nor in F-T systems under conditions for the formation of coarse clots. Under those conditions, protofibrils seem to aggregate easily in the lateral direction ${ }^{3}$ even at a velocity gradient after fibrin monomers polymerize to protofibrils. In the $\mathrm{F}-\mathrm{R}$ systems at $\mathrm{pH} 9.5$, the chromatic polarization was scarcely observed - slightly better in chromatic change than that of fibrinogen. Evidently, both FPA- and FPB-released fibrinogen works to polymerize along the direction parallel to the protofibril axis to form more oriented fibrin intermediate particles than fibrinogen molecules at a velocity gradient. In addition, clots of both FPA- and FPB-released fibrinogen was reported to have structures similar to those of FPA-released fibrinogen but to have a slightly twisted alignment of protofibrils by $\mathrm{Bb}$ bond ${ }^{9}$ bettween complementary polymerization sites. The twisted protoribrils may contribute to form more oriented fibrin fiber intermediates, ${ }^{10,11}$ because of suppressing the speed for the lateral aggregation among polymerization sites of $\mathrm{B}$ and $\mathrm{b}$ polymerization sites, respectively, on $\mathrm{E}$ and $\mathrm{D}$ domains of fibrinogen. ${ }^{9}$

The Reptilase-catalysed fibrin monomer is considered to polymerize quickly perpendicular to the major axis of fibrin intermediate fibers. Therefore, these particles of FPAreleased fibrin intermediates formed at a velocity gradient seem to have an axial ratio of or less than $c a$. 10 , and the average fiber diameter of $90 \mathrm{~nm}$ at the largest. ${ }^{10}$ Also chromatic polarization could not be detected at a velocity gradient lower than $750 \mathrm{~s}^{-1}$ or higher than $2,000 \mathrm{~s}^{-1}$. Thus, observations indicated that fibrin monomer polymerized to eventually form oriented particles in special buffers and at suitable velocity gradients. Moreover, the chromatic polarization in $\mathrm{F}-\mathrm{T}$ systems disappeared with repeated changes of the rotating direction, which should cause from the collapse of oriented particles perhaps owing to collision and aggregation.

The size of protofibrils in a HMG solution was studied by Ferry et al. ${ }^{12}$ These authors found that fibrin monomer, formed in $\mathrm{F}-\mathrm{T}$ systems in a solution of $0.05 \mathrm{M}$ phosphate buffer containing $0.50 \mathrm{M} \mathrm{HMG}$ at $\mathrm{pH} 6.2$ and $9.4 \mathrm{M} \mathrm{NaCl}$, polymerized to a protofibril about $3,500 \AA$ in length and with a cross section double that of fibrinogen, as estimated from light scattering measurements. From the flow birefringence measurements, the length of the protofibril ranged from 3,000 to $5,000 \AA .{ }^{13.14}$ Scheraga and Backus ${ }^{6}$ observed a maximum length of $5,000 \AA$ by stopping the initial polymerization reaction in $\mathrm{F}-\mathrm{T}$ systems by the addition of a concentrated HMG solution. Thus, the hydrodynamic axial ratio of protofibrils are estimated to be $c a$. 50. Actin is well-known to polymerize to a fiber-like structure in $0.1 \mathrm{M} \mathrm{KCl}$. With our data on this investigated structure, the birefringence maximum, plotted in Figure 2, and the corresponding extinction angles are summarized in Tables I and II.

Particles formed in the $\mathrm{pH}$ 9.5, F-T system 
Table I. Relation between clot formation and the occurrence of flow birefringence

\begin{tabular}{|c|c|c|c|}
\hline Used buffer & $\mathrm{F}-\mathrm{R}$ & $\begin{array}{c}\mathrm{F}-\mathrm{T} \\
\chi\left(^{\circ}\right) \Delta n\left(\times 10^{-8}\right)\end{array}$ & $\begin{array}{l}\text { Experimental } \\
\text { conditions }\end{array}$ \\
\hline $\begin{array}{l}\mathrm{pH} 7.0 \\
0.05 \mathrm{M} \text { phosphate } \mathrm{b} .\end{array}$ & $\begin{array}{l}\text { Coarse clots } \\
\text { Non-observable }\end{array}$ & $\begin{array}{l}\text { Coarse clots } \\
\text { Non-observable }\end{array}$ & $\begin{array}{l}\text { See the text } \\
G=1670 \mathrm{~s}^{-1}\end{array}$ \\
\hline $\begin{array}{l}\mathrm{pH} 7.0,0.2 \mathrm{M} \mathrm{NaBr} \\
0.05 \mathrm{M} \text { phosphate } \mathrm{b} \text {. } \\
\text { (Buffer II) }\end{array}$ & $\begin{array}{c}\text { Fine clots } \\
\text { Non-observable }\end{array}$ & $\begin{array}{l}\text { Fine clots } \\
11.8 \quad 252\end{array}$ & $\begin{array}{l}{[\mathrm{F}]=0.923 \mathrm{mg} / \mathrm{ml}} \\
{[\mathrm{T}]=0.0385 \text { units } / \mathrm{ml}} \\
G=1670 \mathrm{~s}^{-1}\end{array}$ \\
\hline \multirow[t]{2}{*}{$\begin{array}{l}\mathrm{pH} 9.5,0.3 \mathrm{M} \mathrm{NaBr} \\
0.01 \mathrm{M} \text { Tris- } \mathrm{HCl} \mathrm{b.} \\
\text { (Buffer I) }\end{array}$} & $\begin{array}{c}\text { Fine clots } \\
\text { Non-observable }\end{array}$ & $\begin{array}{l}\text { Fine clots } \\
12.6 \quad 386\end{array}$ & $\begin{array}{l}{[\mathrm{F}]=0.923 \mathrm{mg} / \mathrm{ml}} \\
{[\mathrm{T}]=0.0769 \text { units } / \mathrm{ml}} \\
G=1670 \mathrm{~s}^{-1}\end{array}$ \\
\hline & Control samples & & \\
\hline $\begin{array}{l}\mathrm{pH} 6.5,0.5 \mathrm{M} H \mathrm{HM} \\
0.05 \mathrm{M} \text { phosphate } \mathrm{b} . \\
0.48 \mathrm{M} \mathrm{KCl}\end{array}$ & Protofibrils & $10.0 \quad 404$ & $\begin{array}{l}{[\mathrm{F}]=0.829 \mathrm{mg} / \mathrm{ml}} \\
{[\mathrm{T}]=1.3 \text { units } / \mathrm{ml}} \\
G=1093 \mathrm{~s}^{-1}\end{array}$ \\
\hline $\begin{array}{l}\mathrm{pH} 8.0,0.1 \mathrm{M} \mathrm{KCl} \\
G \text {-buffer }\end{array}$ & Actin & $2.0 \quad 1151$ & $\begin{array}{l}{[\text { Actin }]=1.10 \mathrm{mg} / \mathrm{ml}} \\
G=73 \mathrm{~s}^{-1}\end{array}$ \\
\hline
\end{tabular}

Table II. Values obtained from flow birefringence measurement of various particles under the same experimental conditions indicated in Table I

\begin{tabular}{cccc}
\hline Particles & $\begin{array}{c}\text { Rotational } \\
\text { diffusion } \\
\text { constant, } \\
D_{\mathrm{r}}\left(\mathrm{s}^{-1}\right)\end{array}$ & $\begin{array}{c}\text { Orientation } \\
\text { factor, } f\end{array}$ & $\begin{array}{c}\text { Expected axial } \\
\text { ratio, } p\end{array}$ \\
\hline $\begin{array}{c}\text { Particles in } \\
\text { Buffer II }\end{array}$ & 60 & 0.51 & $10<p \ll 50$ \\
$\begin{array}{c}\text { Particles in } \\
\text { Buffer I }\end{array}$ & 67 & 0.49 & $10<p<50$ \\
$\begin{array}{c}\text { Protofibrils } \\
\text { Actin }\end{array}$ & 26 & 0.56 & $c a .50$ \\
\hline
\end{tabular}

show values of flow birefringence similar to those measured by Edsall-type apparatus, ${ }^{6,13}$ although the values of their extinction angle are small. The results of the flow birefringence and the extinction angle of actin are consistent with those observed by others, ${ }^{15}$ as is obvious from Table I. The causes of the smaller values of the extinction angle in $\mathrm{F}-\mathrm{T}$ systems, as listed in Table I, should result from the different particles in size and in shape. The $\Delta n$ value of protofibrils in our experiment is close to the value extrapolated to the lower velocity gradient in the data of protofibrils reported by Scheraga and Backus. ${ }^{6}$ The protofibrils in our experiment presumably have, therefore, the same structure with an axial ratio $c a$. 50 as reported by others. ${ }^{6,13,14}$ The apparent length of protofibrils in the absence of $\mathrm{HMG}$ was measured by the flow birefringence apparatus under the velocity gradient of $6,600 \mathrm{~s}^{-1} \cdot{ }^{16} \mathrm{In}$ the $\mathrm{pH}$ region ranged from 7.0 to 9.7 , it almost constantly ranged from 6,300 to $7,000 \AA$. Such a constant length of protofibrils may be grown first in the polymerization process of our experimental conditions, and anisotropic particles, fibrin intermediate fibers, should be formed by the assembly of protofibrils together with the longitudinal growth by binding at a polymerization site revealed after the release of FPB.

Optically anisotropic particles were formed in F-T systems for $\mathrm{pH} 7.0$, the solution exhibited lower flow birefringence than in $\mathrm{F}-\mathrm{T}$ systems for $\mathrm{pH}$ 9.5. As listed in Table II, some aspects of structure of the particles can be inferred from relations ${ }^{17}$ among the flow bire- 
fringence data, orientation factor of particles, rotational diffusion constant of Perrin's equation, calculated for a rigid ellipsoid of rotation, and hydrodynamics of macromolecules. In eq 1 , numerals for the orientation factor of particles formed at $\mathrm{pH} 7.0$ and $\mathrm{pH} 9.5$ in $\mathrm{F}-\mathrm{T}$ ststems are similar, and the values for $\left(g_{1}-g_{2}\right)$ should be different depending on their $\Delta n$ values. Since the intrinsic birefringence is regarded as the same, both particles should be different in the form birefringence. That is, the structural differences may result from a smaller axial ratio of the particles formed at $\mathrm{pH} 7.0$ than those formed at $\mathrm{pH}$ 9.5. The structure cannot be well-approximated by a rigid ellipsoid of rotation but probably more flexible and less viscous, resulting in reduced hydrodynamic friction under a velocity gradient. The differences of two structures at high or at neutral $\mathrm{pH}$ seem to depend on the rate of FPAand FPB-release by thrombin. The rate of FPB release became greater at higher $\mathrm{pH} .{ }^{18}$ The desAABB-fibrin monomer appears to play a role in the formation of more oriented particles at $\mathrm{pH} 9.5$ for the above-mentioned reasons.

In conclusion, flow birefringence was observed in the polymerization process of fibrin monomer hydrolyzed by thrombin under experimental conditions for the formation of fine clots. The removal of both FPA and FPB from fibrinogen was required for the formation of oriented particles under a velocity gradient. Thus, optically anisotropic particles formed by thrombin could be distinguished from particles formed by Reptilase as indicated by flow birefringence observation. In other words, our observation was concluded to be carried out on the process of the formation step (3), which is expressed in the following scheme on the basis of many reported results on fibrin assembly under non-velocity gradients of fibers through fibrin intermediate fibers.

\section{SCHEME FOR FIBRIN ASSEMBLY}

(1) $\mathrm{F}+\mathrm{T} \rightleftharpoons \mathrm{T}+f^{\mathrm{a}}+\mathrm{FPA}+\mathrm{FPB}$

(2) $n \cdot f \rightleftharpoons$ protofibril $n \propto 15$

lateral aggregation 9

(3) $m \cdot$ protofibrils

fibrin intermediate fibers ${ }^{10,11} \rightleftharpoons$ fiber aggregation branching

(4) fibers $\stackrel{\text { crosslinking }}{\rightleftharpoons}$ fibrin $\left(\begin{array}{l}\text { coarse clots } \\ \text { fine clots }\end{array}\right)$

a $f$ indicates fibrin monomer.

Acknowledgements. The authors would like to thank Prof. S. Hatano and Dr. N. Kobayashi in Nagoya University and Prof. T. Masuda in Kyoto University for helpful discussions on flow birefringence. Prof. Y. Ichikawa and Dr. K. Takagi in Kyoto University are gratefully acknowledged for the measurement of actin.

\section{REFERENCES}

1. D. D. Ferry and P. R. Morrison, J. Am. Chem. Soc., 69, 388 (1947).

2. M. F. Müller, H. Ris, and J. D. Ferry, J. Mol. Biol., 174, 369 (1984).

3. M. D. Bale, M. F. Müller, and J. D. Ferry, Biopolymers, 24, 461 (1985).

4. S. V. Pizzo, M. L. Schwartz, R. L. Hill, and P. A. McKee, J. Clin. Inv., 51, 2841 (1972).

5. T. C. Laurent and B. Blombäck, Acta Chem. Scand., 12, 1875 (1958).

6. H. A. Scheraga and J. K. Backus, J. Am. Chem. Soc., 74, 1979 (1952).

7. J. T. Edsall, J. F. Foster, and H. Scheinberg, J. Am. Chem. Soc., 69, 2731 (1947)

8. C. S. Hocking, M. Laskowski; Jr., and H. A. Scheraga, J. Am. Chem. Soc., 74, 775 (1952).

9. S. A. Olexa and A. Z. Budzynski, Proc. Natl. Acad. Sci. U.S.A., 77, 137 (1980).

10. J. W. Weisel, C. Nagaswami, and L. Makowski, Proc. Natl. Acad. Sci. U.S.A., 84, 899 (1987).

11. J. W. Weisel, Biophys. J., 50, 1079 (1986).

12. J. D. Ferry, S. Shulman, K. Gutfreund, and S. Katz, J. Am. Chem. Soc., 74, 5709 (1952).

13. J. F. Foster, E. G. Samsa, S. Shulman, and J. D. 
Ferry, Arch. Biochem. Biophys., 34, 417 (1951).

14. J. D. Ferry, S. Shulman, and J. F. Foster, Arch. Biochem. Biophys., 39, 387 (1952).

15. H. L. Yin, K. S. Zaner, and T. P. Stossel, J. Biol. Chem., 255, 9494 (1980).

16. J. K. Backus, M. Laskowski, Jr., H. A. Scheraga, and
L. F. Nims, Arch. Biochem. Biophys., 41, 354 (1952).

17. H. A. Scheraga, J. T. Edsall, and J. O. Gadd, Jr., $J$. Chem. Phys., 19, 1101 (1951).

18. B. Blombäck, B. Hessel, H. Desmond, and L. Therkildsen, Nature, 275, 501 (1978). 